\title{
A pedagogical response to the challenges of delivering collaborative probation education in online environments
}

\author{
Martin, Laura and Fowler, Andrew \\ Sheffield Hallam University, UK
}

\begin{abstract}
This paper explores the challenges in delivering post graduate probation education in a predominately online environment. It discusses the key pedagogical theories underpinning the teaching approach, with a particular emphasis on social constructivism, communities of practice and enquiry based learning. The complexities of engaging students in the types of discursive and collegiate activities inherent within these approaches whilst learning at a distance are discussed. A case study exploring the facilitation of a colloborative enquiry based task into the role of emotion work in probation practice is used to demonstrate our response to the challenges identified. Whilst the context of this paper is probation education, it has relevance to those teaching other disciplines within online settings.
\end{abstract}

Keywords: Technology Enhanced learning; Digital Pedagogy; Probation Education; Professional Qualification in Probation 


\section{Introduction}

The implementation of the Transforming Rehabilitation policy reform (Deering and Feilzer, 2015), introduced a mixed economy approach to probation services; splitting the state run probation service into public and private providers of probation. This has had consequences for the probation qualification, the learning experience and the teaching approach within higher education for those training to be probation officers. This paper explores how we have sought to adapt to the new probation landscape within the module, Skills for Probation Practice (a core component of the Professional Qualification in Probation); focusing on the use of communities of learning, facilitated by the use of WhatsApp to engage students learning about emotion work in probation.

There are a number of theoretical approaches which have influenced our teaching practice within the Professional Qualification in Probation, notably Biggs and Tang's notion of constructive alignment (2007), McGregor's theory of X and Y learners (1960) and a social constructivist approach (Mathieson, 2015). All of these theories focus on the reciprocal roles of both students and teachers in facilitating successful learning. Knowledge is not simply transferred but is constructed in a collaborative endeavour, within an effective learning environment (Biggs and Tang, 2007). Here we want to pay particular attention to the challenges of creating these learning environments within the context of professional probation education and to reflect on the use of enquiry based learning and communities of practice as effective teaching approaches (Kahn and O'Rourke, 2004, Wenger-Traynor et al, 2015). Both of these practice models support student self-efficacy in their role of constructing and directing their own learning as well as the establishment of "rootedness" within professional practice (Ashton and Stone, 2018: xviii). This links well to the notion of curriculum as praxis, to focus on how the theory, skills and knowledge created with and by the students can then be applied and enacted both within and outside the module. Grundy (1987) describes this as a dynamic interaction which involves both an active and a reflective component. We will further explore this approach in relation to the development of an enquiry based learning task undertaken by our professional practice students which culminates in a community discussion within an online forum.

\section{The context of postgraduate probation education}

The Professional Qualification in Probation (PQiP) consists of five modules taught over a twelve month period, with only twelve hours of face to face teaching time and the rest of the teaching and learning taking place in online environments. This creates challenges for a social constructivist approach in that learners have a very limited opportunity to engage in discursive, collegiate activities and much of their learning take place in isolation. This inhibits their ability to engage with their fellow learners and debate and test out their 
understanding and construct meaning (Mathieson, 2015). In order to better understand the structure and delivery of this professional qualification, it is first important to set this programme in the wider context of education and criminal justice policy.

Whilst probation education has escaped from some of the more significant recent changes in higher education; the rising influence of the government, ideologically driven changes and the role of the market have equally changed the face of the probation landscape as they have in education (Foskett, 2011, Burke and Collett, 2015). Due to the partial privatisation of the field of probation work there have been consequences for probation education, with a key issue being the time and space learners have to devote to their studies. The vast majority of the probation service has now been privatised and there are now multiple operators in this field, with different practice models and expectations of their staff (Deering and Feilzer, 2015). This greater incursion of the market into probation and education has created spaces that can be problematic and fraught with dilemmas. Some of these dilemmas relate to inconsistencies across providers in relation to access to technology and a lack of parity in relation to support mechanisms as well as the organisational challenges associated with reducing staff numbers and poor performance (HMIP, 2017). These problematised spaces impact on the way in which the teaching is structured as we are responding to different agency priorities in terms of the content of our modules. Honig (1996) offers a further perspective on dilemmatic spaces as being those where decisions have to be made but all the outcomes have negative consequences. In the context of our PQiP learners this is usually the decision about whether to neglect work or study in the face of competing demands and, with the responsibilities involved in managing individuals on probation, it is likely that studying is de-prioritised in these situations (Ansbro, 2006).

\section{Challenges within the delivery of postgraduate probation education}

This new landscape has led to a focus on developing our skills and creativity in online teaching and learning, considering the flexibility of our pedagogy in line with Gordon's approach to technology enhanced learning (2014). Whilst the PQiP learners are vocal and engaged in the teaching sessions, the challenges they face regarding their engagement with online learning need to be addressed. They are full time employees, with a caseload of service users alongside the requirement to complete a vocational qualification and the graduate diploma in community justice. These pressures can create an environment which increases the likelihood that students engage with superficial strategies of engagement and surface learning, where they are motivated by successful completion of assessments as opposed to a desire to enhance their theoretical knowledge and application (Biggs and Tang, 2007). 
In recent face to face sessions, the majority of learners highlighted that the pursuit of such knowledge was a key priority for them and as such it is clear that there is motivation to learn and engage, at least at this early stage in their qualification. It is therefore essential that our teaching approaches capitalise on this intrinsic motivation and mitigate the potential for this to be diminished by external, structural pressures. In order to achieve this, online discussions with staff have been planned and a WhatsApp group set up to allow staff and students to interact more informally and this will be used to promote these learning activities, focusing on linking to the content of the module workbook. In particular the use of WhatsApp was motivated by a desire to place ourselves where the learners locate themselves, after attempts to engage them with blackboard discussion boards was unsuccessful (Purvis et al, 2016). On a wider scale, techniques of differentiation and signposting of areas which are essential and those which are more developmental/optional have been additional strategies that have been employed to support engagement and motivation within the online learning materials (Ashton and Stone, 2018).

Whilst Fox's teaching typologies can be viewed as somewhat dated, they offer a perspective on online teaching at its best and worst (1983). One of our main concerns is that the online learning environment does not become simply a mechanism to 'transfer' knowledge and the professional nature of the programme does not encourage us to simply 'shape' the learners in the mould of what we believe is an effective probation practitioner. We want to learners to 'grow' and develop their own perspective on what effective practice looks like and construct their own meaning and understanding. Our question remains as to how we can support the learners to achieve this at a distance and how the module can be constructed in a way that best facilitates this. Fox's metaphor of the guide has resonance with FentonO'Creevy et al's (2015) discussions of practice based education and the way in which students negotiate their route through a multitude of landscapes, both academic and professional. We do not want the learners to feel like 'tourists' within the academic environment and whilst they may not decide to take up residence within this sphere, we hope that they will interact and engage in a way that has a transformative impact on their professional identity.

Gordon (2014) also provides some useful guidance around the role of flexibility within the online teaching environment and has encouraged us to think about this ontologically, pedagogically and systematically. From an ontological perspective this is about some of the issues already discussed about time and space for learning but also about students' ability to engage with different learning environments and approaches. From a pedagogical perspective this is about ensuring that enquiry based learning and communities of practice are the right approaches as well as building in greater mechanisms for formative assessment - outside of formal formative submission points, of which this proposed intervention is an example. Finally, systematically this is about the wider probation education team viewing 
the course structures to ensure that the learning and teaching can be done effectively. It is hoped that by paying greater attention to these dimensions of flexibility, a more 'creative and empowering' relationship between the students and the online learning environment can be developed to facilitate the social construction of knowledge (Burnett, 2011). As the learners are immersed in practice, they become the experts in their own experience and their engagement with the learning community actually helps the epistemological development of the field (Farrell, 2001).

With particular attention being paid to the ontological and pedagogical dimensions of Gordon's (2014) approach as well as notions of enquiry based learning (Kahn and O'Rourke, (2004) and communities of practice (Wenger-Traynor et al, 2015), we have developed a collaborative formative assessment opportunity. This supports Grundy's (1987) view of curriculum as praxis and encourages students to construct their own perspectives on key practice areas as well as engage with their community of practice to test out these views and further contribute to the social construction of knowledge (Mathieson, 2014). Students are first asked to read a key text regarding the role of emotional literacy in working with offenders, they will then respond to a range of questions regarding the relevance of this approach to their own practice, reflecting on their professional values and identity. The students will be asked to record their answers on a Google Form, allowing us to collate and analyse their responses in addition to providing a structured way for them to respond to the questions. This will be followed by an online group discussion, evidencing the above approaches whereby students shape both the construction and application of knowledge with probation practice. Following on from these community discussions, the students will be asked to respond to a further Google Form to collect feedback on the relevance of the task as well as the manner in which it was facilitated. This will allow us to address the last of Gordon's (2014) dimensions and reflect on the structural operation of the programme. By gathering this feedback we are also seeking to ensure that the module is constructively aligned and that learners are provided with opportunities to engage with deep learning (Biggs and Tang, 2007).

\section{The importance of emotion work in postgraduate probation education}

In order to further justify the approach to learning we have taken with regard to this activity and support the assertion that this module is constructively aligned (Biggs and Tang, 2007), it is important to explore the relevance of emotional work to effective probation practice. As discussed above, learner time is scarce and such, it is important that we utilise these occasions to focus on key aspects of professional probation education.

The relationships between practitioners and service users have fallen in and out of favour in terms of both research and policy, throughout the history of the probation service (Burnett 
and McNeill, 2005). Emotion work is difficult to capture and measure and as such it has not been included within the standards governing probation practice (NOMS, 2015). Thus a paradox ensues, with assessment and management of risk and the protection of the public being heralded as the core components of practice yet the need to draw on emotions in order to perform these tasks was effectively ignored (Knight, 2014). Karsetdt et al (2011) argue that the landscape of criminal justice is emotionally charged and this is exemplified by Bottom's (1995) notion of popular punitivism, whereby the collective emotional perspectives of the public are seen to influence the operation of politics and the enactment of policy. The experiences and 'stories' of victims, witnesses and offenders are emotionladen and Knight (2014) recognises the need for practitioners to be skilled in understanding and managing their own emotions as well as those of service users and their victims. She further suggests that it is through practitioners' ability to hear these stories and regulate their responses, that they can help service users begin the process of change.

The relationship between the service user and their worker thus provides the context in which the sharing of these stories takes place and where the construction of new, pro-social identities can begin. The desistance literature offers a renewed focus on these relationships and evidences their importance in encouraging service users to see the potential for their 'future selves' and in promoting optimism for change (McNeill and Weaver, 2010). However, Trotter (2015) suggests caution around the use of emotions, with a specific focus on empathy, highlighting that practitioners need to couple the use of empathy with effective pro-social modelling to ensure that service users do not misconstrue this understanding with tacit approval of their behaviour.

Therefore it can be argued that it is not only important for learners to have an understanding of the value of the productive use of emotions within their practice, but also to have an opportunity to explore how these skills can be effectively deployed. Thus the proposed activity facilitates the learners to conduct their own enquiries into this area of practice. This is then scaffolded by an opportunity to interact with their peers and tutors in a community of learning, whereby they can test out their understanding and also help to construct practice based knowledge and application. This collaborative endeavour acts to enhance the learners 'rootedness' within their profession and enhances their status as active participants in their community of practice (Wenger-Traynor et al, 2014, Ashton and Stone, 2018).

\section{Conclusion}

This paper has sought to explore the challenges of delivering effective probation education in an online environment, with particular attention being paid to the way in which students participate in the social construction of knowledge (Mathieson, 2015). At this stage the 
enquiry based activity has not been undertaken and as such our hypothesis that this enquiry based task, facilitated in a collegiate manner will promote deeper learning and increased engagement has yet to be tested. It is the authors' intention to further develop this paper, with analysis of the students' contributions and their feedback as well as our own reflections on how this activity has achieved our objectives.

\section{References}

Ansbro, M. (2006) Serious Further Offence Inquiry, Probation Journal, 53(2): 167-169

Ashton, S. and Stone, R. (2018), An A-Z of Creative Teaching in Higher Education, London: Sage

Bottoms, Anthony E. (1995) 'The philosophy and politics of punishment and sentencing', in Chris Clarkson and Rod Morgan (eds) The politics of sentencing reform, pp. 1549. Oxford: Clarendon

Briggs, J.B. and Tang, C.S. (2007) Teaching for quality learning at university: what the student does, Maidenhead : Open University Press

Burke, L. and Collett, S. (2014) Delivering Rehabilitation: The politics, governance and control of probation, London: Routledge

Burnett, R. and McNeill, F.(2005). The place of the officer-offender relationship in assisting offenders to desist from crime. Probation Journal, 52(3), 221-242

Deering, J. and Feilzer, M. (2015), Privatising Probation: Is Transforming Rehabilitation the end of the probation ideal? Bristol: Policy Press

Entwistle, N.J. (2009), Teaching for Understanding at University: deep approaches and distinctive ways of thinking, Basingstoke: Palgrave Macmillan.

Farrell, L. (2001), Negotiating knowledge in the knowledge economy: Workplace educators and the politics of codification, Studies in Continuing Education, 23(2): 201-14

Fenton-O'Creevy, Brigham, L., Jones, S. and Smith, A (2015) in E. Wenger-Traynor, M. Fenton-O'Creevy, S. Hutchinson, C. Kubiak, and B. Wenger-Traynor. (2015) Learning in Landscapes of Practice: Boundaries, Identity and Knowledgeability in Practice Based Learning, London: Routledge

Foskett, N. (2011) in M. Molesworth, P. Scullion and E. Nixon, The Marketisation of Higher Education and the Student as Consumer, London: Routledge

Fox, D. (1983). Personal Theories of Teaching, Studies in Higher Education, 8, 151-163

Gordon, N. (2014), Flexible Pedagogies: technology-enhanced learning, York: Higher Education Academy

Grundy, S. (1987). Curriculum : Product or praxis? Falmer. 
Her Majesty's Inspectorate of Probation (2017), Annual Report, London: HMIP

Higher Education Academy (2011), United Kingdom Professional Standards Framework, York: Higher Education Academy

Honig, B. (1996). Difference, dilemmas, and the politics of home. In S. Benhabib (Ed.), Democracy and Difference. Contesting the Boundaries of the Political. (pp. 257277). New Jersey: Princeton University Press.

Kahn, P. and O'Rourke, K. (2004), Guide to Curriculum Design: Enquiry Based Learning, York: Higher Education Academy

Karstedt, S., Loader, I. and Strang, H, (2011), Emotions, Crime and Justice, Oxford: Hart

Knight, C. (2014), Emotional Literature in Criminal Justice, Basingstoke: Palgrave Macmillan

McGregor, D. (1960) as cited by: Briggs, J.B. and Tang, C.S. (2007) Teaching for quality learning at university: what the student does, Maidenhead : Open University Press

McNeill, F. and Weaver, B. (2010) Changing Lives? Desistance Research and Offender Management: The Scottish Centre for Crime and Justice Research.

Mathieson, S. (2015) Student Learning, In: H. Fry, S. Ketteridge and S. Marshall A Handbook for Teaching and Learning in Higher Education, Oxon: Routledge

National Offender Management Service (2015) National Standards for the Management of Offenders in England and Wales, London: Ministry od Justice

Purvis, A., Rodger, H. and Beckingham, S. (2016) Experiences of social media in higher education: barriers, enablers and next steps. In: Social Media for Learning in Higher Education 2015 Conference proceedings (\#SocMedHE15). Sheffield: Sheffield Hallam University.

Trotter, C. (2015), Working with Involuntary Clients: A guide to practice, London: Routledge

Wenger-Traynor, E., Fenton-O'Creevy, Hutchinson, S., Kubiak, C. and Wenger-Traynor, B. (2015) Learning in Landscapes of Practice: Boundaries, Identity and Knowledgeability in Practice Based Learning, London: Routledge 